\title{
WRITING LEARNING STRATEGY AND READING POETRY BASED FOR TRADITIONAL GAMES CRITICAL THINKING PROCESS
}

\author{
Masayu Gay* \\ STKIP Kie Raha Ternate, North Maluku, Indonesia
}

\begin{tabular}{|c|c|}
\hline ART ICLE INFO & A B S T R ACT \\
\hline $\begin{array}{l}\text { Keyword: } \\
\text { Critical thinking, } \\
\text { learning to write and read } \\
\text { poetry, } \\
\text { traditional games }\end{array}$ & $\begin{array}{l}\text { Critical thinking is the thinking ability that must be possessed by students through } \\
\text { learning to write and read poetry. The indicators of critical thinking ability in writing and } \\
\text { reading traditional game-based poetry are (1) knowing the problem, (2) collecting and } \\
\text { compiling information, (3) organizing, (4) analyzing, (5) reconstructing, (6) informing, 7) } \\
\text { apply or inform. The process of critical thinking in learning to write and read poetry based } \\
\text { on traditional games (egrang) can develop critical thinking skills of elementary school } \\
\text { students, with learning styles, first, teachers review the curriculum and formulate basic } \\
\text { competencies and competency standards. Second, teachers and students make } \\
\text { observations. Third, Teacher ensures that students have experience playing stilts. Fourth, } \\
\text { students practice traditional game play. Fifth, teachers and students are elaborating. Sixth, } \\
\text { students collaborate to record the materials used as a game. Seventh, the stage of writing } \\
\text { and reading poetry. Eighth, the stage of communicating. Ninth, stage of reflection. This } \\
\text { learning model can train students' thinking power, provide ease of writing and reading, } \\
\text { fostering cooperation and social sensitivity. The quality of playing stilts, discipline, courage, } \\
\text { patience, focus / concentration, and confidence. }\end{array}$ \\
\hline
\end{tabular}

\section{INTRODUCTION}

One of the skills that must be possessed by learners in the XXI century, marked by the era of globalization and technology is the ability to think critically. Pujiono, revealing the information flow of the era of globalization requires a person capable of thinking critically (critical thinking), the ability to filter intelligently and is responsible for information that is still questionable its validity (Pujiono, n.d.). This skill is responded by the government through the national education system in Permendikbud Number 21 of 2016 on Content Standard (CS), which explains the scope of teaching materials. In this Permendikbud the people's game becomes part of the text of Indonesian language and literature learning. This normative reference to answer the future needs and welcome the Indonesian Golden Generation Year 2045. Through the standard of the contents set the competency standards of graduates based on the competence of XXI century and demographic bonus Indonesia. Through content standards, it clearly emphasizes also on critical thinking skills.

Competence of the XXI century, including (1) Having a capability that is ready to work in every area of expertise; (2) Innovative and problem solving; (3) Has a communicative and cooperative way of working (collaboration); (4) Be able to collect information / data and use it; (5) Resourceful in using information technology and media devices; (6) Having integrity and discipline in performing duties and carrying out obligations related to his profession; (7) Character of global citizen; and (8) Have critical thinking skills, and creative (Kamdi, 2017).

Indicator of critical thinking skills according to Fisher, 1) Know the problem; 2) Knowledgeable ways to deal with such problems; 3) Collecting and compiling important information; 4) Knowing axiomatic or asumtif, as well as unspecified values; 5) Understand and use appropriate, clear, and distinct

\footnotetext{
" Corresponding author.

E-mail addresses: masayugay@stkipkieraha.ac.id (Masayu Gay)
}

ISSN : 2597-7385 (Online) - ISLLAC : Journal of Intensive Studies on Language, Literature, Art, and Culture is licensed under Creative Commons Attribution-ShareAlike 4.0 International License (http://creativecommons.org/licenses/BY/4.0/).

62 | ISLLAC : Journal of Intensive Studies on Language, Literature, Art, and Culture 
diction; 6) Analyzing data; 7) Assess facts and evaluate statements; 8) Recognize the logical relationship between problems; 9) Draw the necessary conclusions and similarities; 10) Examine the similarities and conclusions one takes; 11) Rearrange one's belief patterns based on wider experience, and; 12) Make appropriate judgments about certain things and qualities in everyday life (Fisher, 2009).

According to Colley \& Bilics the ability to think critically is a habit of thinking characterized by a comprehensive exploration of ideas, issues, and events before accepting or formulating an opinion or conclusion (Colley \& Bilics, 2012). Peter (2012), the ability to think critically can see as an intellectual field accompanied by active, skillful, conceptualizing, implementing, reviewing, connecting, and evaluating information obtained through observation, experience, reflection, reasoning or communication as a guide to trust and action (Peter, 2012).

Learning to write and read poetry is a literary skill that must be possessed learners. This skill is expected to develop students' critical thinking ability optimally. Some reasons for the importance of critical thinking skills through learning to write and read, because writing can be a means to find something, create new ideas, train organizational skills, and clarify concepts or ideas, train objective attitudes on individuals, help obtain and process information, as well as train critical, creative thinking skills. To achieve critical competence, it requires innovation of teachers in the learning process. In other words, the teacher is in charge of developing innovative learning models. According to Zamroni and Mulyasa, the quality and readiness of teachers determines the achievement of the quality of education, because the teacher is a central figure in the learning process (Zamroni, 2000; Mulyasa, 2002). Bayne-Jardine et al., Emphasizes enhancement of motivation and development of pedagogical skills (Bayne-Jardine et al., 2005; Sifuna, 2007).

The learning model of writing and reading traditional game-based poetry is a model that is considered to have innovation aspects to develop students' critical thinking skills. Some research with database is literature as a form of local wisdom to improve the critical ability, character, problem solving, communication ability has been done. The study, among others, local wisdom (Tau Jo Nan Ampek) for the development of character education model character in high school has been done by Jamrah (2017). The results of this study are in accordance with the explanations of Bahri et al., And Dewi et al, that to improve skills, such as critical thinking, problem solving, creativity, the ability to communicate and collaborate and have the capability in information technology (Bahri et al., 2017; Dewi et al., 2017).

Learning to write and read poetry using traditional games is a contextual learning. The game is considered appropriate, because the child at elementary school age is the age of play. Through learning while playing will create positive emotions in children. According to Oxford, the implications for language learning are related to understanding and managing emotions; expressing emotions appropriately despite cultural and linguistic differences. Anxiety has an adverse effect on second-language learners, so reducing anxiety regarding learning a second language is important (Chen and Lee, 2011) 1; Oxford in (Challenges of second and foreign language education in a globalized world, 2017). Referring to Oxford's explanation, the use of traditional games creates positive emotions that affect literary learning.

Traditional games that exist in the regions that exist in the territory of Indonesia has a variety of forms and also various ways to play it. It also has various names given to the game forms, sometimes the same kinds of games. However, the name given in the area with one in another area is different. This traditional game has not been used as a medium of learning, except for a game only.

The use of traditional games can place the values of local wisdom as a learning context potentially bringing the learners closer to their living environment: from the customs and cultural objects where the values are embedded and embedded in them. Thus, traditional game utilization strategies are part of the seedling and value-feeding process. When learners interact and adapt to the environment (culture), they are actually in the learning event. The cultural environment is a "locus" to gain experience (new experiences). Traditional games integrated into language education praxis will create an exploration field for learners in understanding and live a certain value.

Learning to write and read traditional game-based poetry has a positive impact on the development of literacy and critical thinking of students. In addition, learning that integrates traditional games will revive the cultural values of society. Besides raising the competence of multicultural learners. Peter, advocated language learning through an anthropological approach to reshape literacy education in relation to cultural and linguistic hybridity and hybridity in most schools and workplaces (Peter Freebody in his book (Street and May 2017).

The positive impact of learning to write and read poetry through traditional games is intended to make students think globally, but not parting from local identity. Forgetting her habitat, leaving her country's cultural heritage, and no longer cares about her own brother. The UNESCO Declaration on Cultural Diversity, states: Culture should be regarded as a spiritual, material, intellectual and emotional set 
of distinctive features of society or social groups, and it includes, in addition to art and literary arts, lifestyles, ways of living together, value systems, traditions and Furthermore, Dolphen and Hamsial, local knowledge can be utilized for language and cultural teaching media (Dolphen, 2014; Hamsiah et al., 2017). According to Meliono, appropriate teaching methods for presenting teaching materials using Nusantara thought, local wisdom, and multiculturalism are important steps to take as globalization has been rapid in education, science, and technology (Meliono, 2016).

Through traditional game-based learning not only enables learners to understand, but also doing it, and interact with it through various processes: knowing, doing, and being integrated. Therefore, the learning model through the traditional game is a learning that involves the students directly to obtain information to make a decision. This is in accordance with Abdullah's explanation, that after the information obtained how to use the information appropriately / appropriate to make a decision (Abdullah, N. 2013). According to Pujiono, there is the character of an individual capable of critical thinking, always questioning an argument used to obtain the ultimate truth. Because critical individuals always see things sharply, comprehensively, comprehensively, analyze in detail, and make judgments with reliable indicators (Pujiono, n.d.).

The focus of this paper is writing on the critical thinking skills in traditional game-based writing and reading lessons. The indicator of critical thinking ability in this paper refers to the five critical thinking steps of Pujiono elaborated with two indicators of critical thinking by Fisher. Five steps critical thinking by Pujiono, namely (1) the ability to remember, (2) organize, (3) analyze, (4) reconstruct, and (5) rate (Pujiono, n.d.). Two indicators by Fisher, that is knowing the problem, collect and compile information. The author adds two indicators, which inform and apply or apply. Therefore, the results of collaboration indicators of critical thinking ability in writing expenditure reading traditional game-based poetry are (1) knowing the problem, (2) collecting and compiling information, (3) organizing, (4) analyzing, (5) reconstructing, (6) ) informs, and (7) implements/informs.

\section{DISCUSSION}

\section{Philosophical Foundation of Literature Learning}

Like learning in general, literary learning departs from the hierarchy of learning as the mother of science, from learning philosophy, learning theory, approaches, strategies, methods, and learning techniques. These hierarchical components form a learning design called the learning model. Philosophy refers to the views of one's life/individual. The view of life as the universal values of a nation becomes a benchmark for the development of learning. When reviewed comprehensively, the philosophy that underlies the learning of writing and reading traditional game-based poetry is the philosophy of constructivism. According to Prastowo (2014), the flow of constructivism emphasizes the direct experience of students as the primary key to learning. In this case, the content or content of the learning materials is related to the experience of the students directly so that the learning is more contextual with the real world of the students. According to the view of the flow of constructivism, students 'knowledge is the result of students' constructions through interaction with objects, phenomena, experiences, and the environment. Knowledge gained is not based on the mere transfer of knowledge by the teacher but the conscious effort of the students in interpreting their own knowledge or concepts obtained. Therefore, constructivism does not focus on the outcomes shown, but rather focuses on a continuous process of sustainability.

Approach is axiomatic or asumption, in science approach is defined as a proposition. In the process of learning the teacher has to do assumptions that he considered correct. In other words, the teacher assumes that if an action is taken, it will work. For example, learning it takes practice. Learning it must be full of examples. Learning it needs a feedback backwards. Based on these assumptions, the teacher also determines the correct theory. For example, teachers think learning is a stimulus-response, then the theory is behaviorism. Theory is constructive. After that, from theory to the first hierarchy, that is philosophy. For example, philosophy of behaviorism. Strategy is a series of actions of teachers and students in learning. Therefore, learning strategy must be clear step / syntax learning. The method is the way of conveying the material, while the technique is real in the learning process. Philosophical understanding of learning helps teachers in choosing learning models that fit the learning objectives.

In the context of learning to write and read poetry is the same. All of the above hierarchies need to be benchmarks, references, directions, or guidelines. Especially the hierarchy of philosophy as the highest hierarchy. In the context of learning, for example, literary texts that are written or used as teaching materials, consider the philosophical aspect. For example, the contents of poetry written and read do not contain harassment in certain groups and religions. Or the emergence of stereotypes for other groups. So, it should be considered as a text of learning to students. Because the text can threaten the integrity of the 
nation. Therefore, the philosophical framework, namely Pancasila and the 1945 Constitution, becomes the basis for decision making to formulate a model of learning. In other words, the teacher should avoid the poetical text that contradicts the philosophical foundations of the Indonesian nation.

The above description, in line with Suyitno's view, that philosophical basis of education should be a philosophical starting point, that is a more comprehensive, speculative, and normative approach. Thus, the teacher first deepens his philosophical foundation. Therefore, the nature of education is humanization (Suyitno, 2009). Therefore, Pancasila humanism became the foundation of the philosophy of learning in Indonesia. In other words, the national education outline breathes pancreatic humanism. This is the figure for learners who want to be generated through literary learning, especially writing and reading poetry.

\section{Basic Concepts of Writing and Reading Poetry Learning}

As a type of literary work, poetry not only speaks of the self (psychological), but also about the Creator (religiosity), the universe (romantic), and society (sociological). Literature (poetry) can reveal problems from multiple perspectives. One of them as a medium for developing the critical thinking ability of learners, behave individually to live and work together, both in the family environment, society, nation, and country. (Lustyantie and Pd, n.d.). Literary learning and teaching play an important role. In learning, literature plays a role for learners as (1) language development, (2) cognitive development, (3) personality development, and (4) social development (Tarigan, 1995).

In the 2013 curriculum of 2017 revision, Indonesian language learning should be integrated between listening, speaking, reading, and writing. Or at least two language skills should be integrated into the learning model. The same thing in the study of literature. Therefore, in this writing, the components of writing and reading are integrated into traditional game-based learning.

\section{The concept of Critical Thinking}

According to Colley \& Bilics the ability to think critically is a habit of thinking characterized by a comprehensive exploration of ideas, issues, and events before accepting or formulating an opinion or conclusion (Colley \& Bilics, 2012). Peter (2012), the ability to think critically can see as an intellectual field accompanied by active, skillful, conceptualizing, implementing, reviewing, connecting, and evaluating information obtained through observation, experience, reflection, reasoning or communication as a guide to trust and action (Peter, 2012). Five steps critical thinking by Pujiono, namely (1) the ability to remember, (2) organize, (3) analyze, (4) reconstruct, and (5) rate (Pujiono, n.d.).

\section{Critical Thinking Indicators}

Indicator of critical thinking skills according to Fisher, 1) Know the problem; 2) Knowledgeable ways to deal with such problems; 3) Collecting and compiling important information; 4) Knowing axiomatic or asumtif, as well as unspecified values; 5) Understand and use appropriate, clear, and distinct diction; 6) Analyzing data; 7) Assess facts and evaluate statements; 8) Recognize the logical relationship between problems; 9) Draw the necessary conclusions and similarities; 10) Examine the similarities and conclusions one takes; 11) Rearrange one's belief patterns based on wider experience, and; 12) Make appropriate judgments about certain things and qualities in everyday life (Fisher, 2009).

\section{Critical Thinking Ability Indicators in Learning to Write and Read Poetry Based on Traditional Games}

The focus of this paper writing on the ability to think critically about the learning of writing and reading poetry based on the traditional game of children. The indicator of critical thinking skills in this paper refers to twelve indicators by Fisher. Because of the consideration of primary school learners, the author limits it to five, (1) Knows the problem, (2) Knows how to handle the problem, (3) collects data and writes important information, (4) Uses proper, clear, and typical, (5) Draw conclusions. In addition, the authors add inform and apply.

Indicator of critical reading ability through traditional game-based learning writer adopted Nurhadi (2009), namely (1) ability to remember and recognize, (2) ability to interpret, (3) ability to apply concept, (4) ability to analyze, (5) ability to make synthesis (concluding, organizing, and summarizing, and (6) ability to judge (truth, relevance, and accuracy).

Critical Lesson Writing and Reading Poetry

One of the skills that must be possessed by learners in the XXI century, marked by the era of globalization and technology is the ability to think critically. Pujiono, revealing the information flow of the era of globalization requires a person capable of thinking critically (critical thinking), the ability to filter intelligently and is responsible for information that is still question its validity (Pujiono, n.d.). 
This skill is responded by the government through Permendikbud Number 21 of 2016 on Content Standard (SI). This normative reference to answer the future needs and welcome the Golden Generation of Indonesia Year 2045. Through the Content Standards defined Graduates Competency Standards based on the competence of XXI century and demographic bonus Indonesia. Through content standards, it clearly emphasizes also on critical thinking skills. In SI, the core competency skill for grade I-VI elementary school students can demonstrate creative, productive, critical, independent, collaborative, and communicative thinking skills and acts in clear, logical, and critical language, an aesthetic work, in a movement that reflects the child's behavior according to the stage of development.

To note, that the competence of the XXI century, includes (1) Have a capability that is ready to work on each area of expertise; (2) innovative and problem-solving; (3) Has a communicative and cooperative way of working (collaboration); (4) Be able to collect information / data and use it; (5) Resourceful in using information technology and media devices; (6) Having integrity and discipline in performing duties and carrying out obligations related to his profession; (7) Character of global citizen; and (8) Have critical thinking skills, and creative (Kamdi, 2017).

Learning literature, especially writing and reading poetry in elementary school is expected to develop students' critical thinking skills optimally, according to competence in the SI. Some reasons for the importance of critical thinking skills through poetry learning, because writing poetry can be a means of finding something, generating new ideas, practicing organizing skills, and purifying various concepts or ideas, exercising objective attitudes on the individual, helping to obtain and process information, train critical, creative thinking skills. To achieve critical competence, it requires innovation of teachers in the learning process. In other words, the teacher is in charge of developing innovative learning models. According to Zamroni and Mulyasa, the quality and readiness of teachers determine the achievement of the quality of education, because the teacher is a central figure in the learning process (Zamroni, 2000; Mulyasa, 2002). Bayne-Jardine et al., Emphasizes enhancement of motivation and development of pedagogical skills. (Bayne-Jardine et al., 2005; Sifuna, 2007).

Based on the above description, the learning model through the traditional game is a learning that involves the students directly to obtain information to make a decision. This is in accordance with Abdullah's explanation, that after the information obtained how to use the information appropriately / appropriate to make a decision (Abdullah, N. 2013). According to Pujiono, there is the character of an individual capable of critical thinking, always questioning an argument used to obtain the ultimate truth. Because critical individuals always see things sharply, comprehensively, comprehensively, analyze in detail, and make judgments with reliable indicators (Pujiono, n.d.).

The concept of Traditional Games

Traditional children's fashion is one of the folklore nemtuk existing and circulated orally among certain collective members, traditional shaped, and inherited generically from general to generate. This type of game is spread by word of mouth. when viewed from the roots of it, traditional games are nothing but activities that are governed by certain playing modes which are the heritage of the former society by which the children (the people) got the excitement (Danandjaja quoted Misbach, 2007).

Sukirman explained that the traditional game of children is one element of culture because it can have an impact on the development of psychological progress, social life, and the nature of children (Sukirman, 2008). In addition, traditional games reflect the culture of a particular society. This game can survive, because there are elements of culture in it, as well as high moral values, such as skill, honesty, unity and unity, solidarity, skill, and courage (Depdikbud, 1996). Traditional games are a form of play. This activity is believed to be beneficial for both physical and mental development (Kurniati, 2010).

The use of traditional games can place the values of local wisdom as the context of language education potentially bringing the students closer to their living environment: from the customs and cultural objects where the values are embedded and embedded in them. Thus, traditional game utilization strategies are part of the seedling and value-feeding process. When learners interact and adapt to the environment (culture), they are actually in the learning event. The cultural environment is a "locus" to gain experience (new experiences). The local wisdom that is integrated into language education praxis will create an exploration field for learners in understanding and live a certain value.

Learning to write and read traditional game-based poetry has a positive impact on the development of literacy and critical thinking of students. In addition, learning that is integrated into traditional games, especially writing will revive the cultural values of society. Besides raising the competence of multicultural learners. Peter, advocated language learning through an anthropological approach to reshape literacy education in relation to cultural and linguistic hybridity and hybridity in most schools and workplaces (Peter Freebody in his book (Street and May 2017). 
Through this learning strategy, then the traditional game not only serves as a game tool. However, at the same time, the game becomes a game that can educate. Therefore, the traditional games contained in areas that exist in the territory of Indonesia has a variety of forms and also various ways to play it. In the context of learning, this traditional game has not been used as a medium of learning, except for a game only. Dolphen and Hamsial, local knowledge can be utilized for language and cultural teaching media (Dolphen, 2014; Hamsiah et al., 2017). According to Meliono, appropriate teaching methods for presenting teaching materials using Nusantara thought, local wisdom, and multiculturalism are important steps to take as globalization has been rapid in education, science, and technology (Meliono, 2016).

\section{Learning Strategies for Writing and Reading Poetry}

\section{The strategy of Writing and Reading Poetry Based on Traditional Games for Critical Thinking}

The traditional game of children is very much. For that, at this writing, the authors choose traditional game egrang. Egrang is one of the traditional games that use materials made of two bamboo sticks, each bamboo measuring about 4-5 meters, with a foothold beneath the bamboo, about $50 \mathrm{~cm}$ from the end of the bamboo. This game is to test the player's body balance.

If during this traditional game is only used to play, then at this writing used as well as objects to write and speak. This strategy is used for writing and speaking. In other words, all this time the game only functioned as a tool to play and has not been used as a medium/object that can improve students' language skills. One of the traditional games that teachers can use to increase the difficulty of writing and reading students is egrang.

Based on stimulus-response theory, then learning is the action of stimulus to students before they write and read the results of his writing. In other words, the teacher provides a stimulus through the game. However, teachers initially instruct students to practice stilts before they are told to write and read. Here are some steps/syntax using stilts for learning to write and read. Teachers should know that students have experience about playing egrang.

The quality of playing egrang that, namely discipline, courage, patience, focus/concentration, and confidence. This quality is a requirement for learners to write and read poetry. Through the quality of players egrang then learners know, that start writing and reading poetry must be discipline, courage, patience, focus/concentration, and confidence.

A set of assumptions to write and read poetry through stilts, such as:

1) Through learning-based egrang students can write poetry based on the quality trait egrang players, namely patience, focus, courage, and confidence.

2) Through learning-based egrang students can write poetry based on his observations of the game process.

3) Through learning-based stilts, students can discuss based on his experience in the game egrang.

4) Students already have experience writing egrang experience, then the experience can be used to write poetry.

5) Through the game egrang students dare to ask.

6) Through the game egrang students learn discipline.

Make confidence that learning to write and read traditional game-based poetry for critical thinking skills as the five points above. An assumption is also an approach that arises from the theory of learning. Critical Learning Sintak Poetry Writing:

1) The teacher examines the curriculum and formulates the basic competencies and competency standards in the design of the learning implementation.

2) Teachers and students make observations to identify the game to be used. This step gives the teacher the freedom to the students to choose a favorite game. Students who have the same fondness will be formed in a small group of 4-5 people.

3) Students have experience playing egrang.

4) Students practice traditional gameplay.

5) Teachers and students are collaborating on questions about how to play the game, including the material for making the game.

6) Students in groups collect (data collection) materials used as a game. This data collection activity aims to find the vocabulary for later developed into an essay.

7) The student rewrites the words that have been identified in one essay.

8) Students communicate the work.

9) Teachers and students evaluate and reflect.

Critical Reading Sintak Reading Poetry:

1) The student reads the poetry she has written. 
2) Teachers assess the performance of reading students.

Excellence:

1) Students engage directly, see, feel, and know the objects they learn.

2) Train students to discuss

3) Train students' thinking power.

4) Provide convenience for students who have difficulty writing and reading.

5) Fostering social sensitivity.

6 ) If the game is used for the practice of playing in groups, then train the cohesiveness and mutual cooperation for a game.

7) Play makes a fun time for children.

8) This learning model can develop students' critical thinking skills. Because they will ask critical questions, such as why the material is made of bamboo, why size should be $50 \mathrm{~cm}$, why need balance and so on.

Deficiency: It takes a long time.

Word Stimulus Techniques through Stretch Games

Often we meet students who have difficulty writing, especially novice student students. When asked about what difficulties experienced when you want to write, students usually answer "do not like to write", or do not like Indonesian lessons. For the innovative teacher, the student's problem actually makes the students chance to write. For example, the teacher provides a stimulus with simple questions, such as why you do not like to write, from the question the student finally revealed all the problems that exist in him in a written form. It may include displeasure with the teacher or his or her friend. That's when he (students) wrote. Then, the teacher gives appreciation as a form of feedback to the student's writing. The languages that motivate them to build their confidence. And so on.

Given that elementary school students are the age of initial writing, then the writing activity through this traditional game they should not be pressed on the grammatical system. Let them write first what they write. Grammatical aspects will be corrected students with teachers. It is intended that students are not burdened with the grammatical aspects.

What about writing poetry? What innovative techniques can be done so that students who have difficulty writing poetry can write well? Well, in this case the teacher can apply the technique of dialog journals through the game stilts. The syntax of teachers begins writing poetry of students by asking stimulus questions based on objects (egrang).

I like to play (keywords from students)

Play what you like? (asked teacher)

Answer (student)

Why do you like (asked teacher)

Answer (student)

Who do you like to play with? (asked teacher)

Answer (student)

And so on until the teacher feels has enough to be one poetry. While the poetry reading activity is done after the poem he wrote.

\section{Feedback Technique}

Through the assumption that the learner feels his job/effort must be appreciated by his friends and teachers. The form of appreciation is in the form of appreciation given. This feedback technique can be directly or indirectly. This technique is directly done during the learning process. For example, students and teachers give applause to students who have done their job well. Indirectly done in the form of publications by students in school wall magazines, or in the classroom. Thus, they can see directly the work of the work read by his friends.

Often this way is not done by the teacher. In fact, often tasks students do without being told the teacher how the task. Students also feel that the task is not paid attention, so they consider the task as a burden. 


\section{Characteristics of Primary School Students}

Learners at the elementary level (SD/MI) are individuals who are undergoing developmental period from early childhood to early adolescence. While completing their education in primary school, they are in the early developmental stage of adolescence. Since elementary school is expected to learners gain the knowledge equivalent and very important for the growth of education at the next level. Therefore, they are expected to learn the skills, such as:

1) Self-help skills. At this time the child is able to help himself to adapt to his environment. He is able to solve problems, so as to integrate with the surrounding environment.

2) Social skills. At this time the children are able to socialize, either with a friend of his age and with older people / younger than him.

3) School Skills. At this time children can go to school, follow the learning, and absorb the lesson.

4) Playing skills. Entering the elementary school age, children can play toys for ages like them

Iskandarwassid and Dadang (2008).

Generally, primary school children are easily cared for and directed, compared to the period before and after. This childhood is often called the intellectual period, as they begin to open and begin to desire to continue to gain knowledge and experience (Iskandarwassid and Danang, 2012) quoted by (Hidayah, 2015).

\section{CONCLUSIONS}

Traditional games also teach the values of cooperation sportsmanship, honesty, and creativity. Games that are done individually or in groups teach children to socialize and build cooperation among friends. While modern games do not teach these things. Computer-based modern games make children tend to be social because it is enough to play alone in front of the computer. Not to mention some games that sometimes contain a negative charge. These games if well-grounded will be used as learning resources for the Indonesian language, especially in high-class students. Egrang is one of the traditional games that have quality by players, namely discipline, courage, patience, focus/concentration, and confidence.

Learning model of writing and reading traditional game-based poetry is not only to develop students' critical thinking skills but also to bring students closer to the cultural values of Indonesian society. This is very important because the development of technology in the digital age today leads students to divert all play activities through technological means. As a result, students lose their social sensitivity. Understanding the global dimension must be balanced with the understanding of local dimensions. Thus, students do not lose their own homes as the nation's cultural footing that reflects the values of Pancasila as the philosophical foundation of national and state life.

\section{REFERENCES}

Abdullah, N. (2013). Improve Communication Skills and Mathematical Critical Thinking of Junior High School Students Through Problem Based Learning with Teams-Assisted Individualization (TAI) Strategy. Thesis On SPs UPI. Bandung: Not Published.

Bahri, S., Kusumawati, L., Nuraini, L., 2017. STEAM Education Based On Local Wisdom Of Coffee Plantation In Jember To Improve The Competitiveness at 21st Century. Pancar. Pendidik. 6.

Bayne-Jardine, C., Bayne-Jardine, C.C., Hoy, C., Wood, M., 2005. Improving quality of education. Routledge.

Challenges of second and foreign language education in a globalized world, 2017. Springer Berlin Heidelberg, New York, NY.

Chen, C.-M., Lee, T.-H., 2011. Emotion recognition and communication for reducing second-language speaking anxiety in a web-based one-to-one synchronous learning environment: Emotion recognition for reducing second-language anxiety. Br. J. Educ. Technol. 42, 417-440. https://doi.org/10.1111/j.1467-8535.2009.01035.x

Dolphen, I., 2014. Learning Language and Culture through Indigenous Knowledge: A Case Study of Teaching a Minority Language (Mon) in a Majority Language (Thai) School Setting. Procedia - Soc. Behav. Sci. 134, 166-175. https://doi.org/10.1016/j.sbspro.2014.04.236

Dewi, N.I., Poedjiastoeti, S., Prahani, B.K., 2017. Elsii Learning Model Based Local Wisdom To Improve Students' Problem Solving Skills And Scientific Communication. Int. J. Educ. Res. 5.

Fisher, A. (2009). Critical Thinking: An Introduction: Jakarta. Erlangga.

Maryani, S., \& Erwin, E. (2018). BERBAHASA: POTRET NASIONALISME GENERASI BANGSA. Paedagoria/ FKIP UMMat, 6(2), 51-55.

69 | ISLLAC : Journal of Intensive Studies on Language, Literature, Art, and Culture 
Hamsiah, H., Tang, M.R., Tolla, A., Jufri, J., 2017. Teaching Materials Development for Basic General Course of Indonesian Language Class Based on Culture Values Elompungi (Elong) Bugis Literature. J. Lang. Teach. Res. 8, 278. https://doi.org/10.17507/jltr.0802.08

Iskandarwassid and Dadang Sunendar. 2008. Strayegi Language Learning. Remaja Rosdakarya. Bandung.

Jamrah, A., 2017. Character Education Development Model Based Values" Tau Jo Nan Ampek" At High School Level In the City Batusangkar. Proceeding IAIN Batusangkar 1, 153-164.

Julian M., James and John Alfred. 2008. Learning Personality. Publisher Read: Yogyakarta.

Kamdi, Waras. 2017. Dikti Curriculum in the Whirls of Industrial Revolution 4.0 (Workshop on Curriculum Development of UM Proram Accounting Study, Faculty of Economics, 18 Semeber 2017). Malang State University.

Kurniawati (2010). Let's play! 30 Traditional Games. West Java: Bandung PG Paud UPI.

Lustyantie, D.N., Pd, M., N.D. Building a Character Generation 19.

Meliono, I., 2016. Understanding the Nusantara thought and local wisdom as an aspect of the Indonesian education. Tawarikh 2.

Ridwan, M. (2017). Tradisi Nyanyian Anak terhadap Pembentukan Karakter Anak Usia Sekolah Dasar. Sekolah Dasar: Kajian Teori dan Praktik Pendidikan, 26(1), 49-61.

Ridwan, M., \& Wahdian, A. (2017). STRUCTURE, FUNCTION AND VALUE THE TRADITION OF ORAL LITERATURE IN SUMENEP MADURA. ISLLAC: Journal of Intensive Studies on Language, Literature, Art, and Culture, 1(1), 252-273.

Ridwan, M., \& Ridwan, M. (2016, March). PENDIDIKAN KARAKTER BERBASIS PERMAINAN TRADISIONAL SISWA SEKOLAH DASAR DI SUMENEP MADURA. In PROSIDING SEMINAR NASIONAL "Optimalisasi Active Learning dan Character Building dalam Meningkatkan Daya Saing Bangsa di Era Masyarakat Ekonomi Asean (MEA)" (pp. 131-135). Prodi Pendidikan Guru Sekolah Dasar dan Prodi Bimbingan dan Konseling.

Ridwan, M. (2017). Tradisi Nyanyian Anak terhadap Pembentukan Karakter Anak Usia Sekolah Dasar. Sekolah Dasar: Kajian Teori dan Praktik Pendidikan, 26(1), 49-61.

Pujiono, S., n.d. Critical Thinking in Literacy Reading and Writing to Strengthen the Nation 7.

Prastowo, Andi. 2014. The development of thematic materials. Jakarta: Kencana.

Sifuna, D.N., 2007. The Challenge of Increasing Access and Improving Quality: An Analysis of Universal Primary Education Interventions in Kenya and Tanzania since the 1970s. Int. Rev. Educ. 53, 687699. https://doi.org/10.1007/s11159-007-9062-z

Sukirman. 2008. Smart Giving for Kids 2 - 6 Years. Jakarta: Erland.

Suyitno. 2009. The Foundation of Education Philosophy. Open University, Faculty of Education: Jakarta.

Street, B.V., May, S. (Eds.), 2017. Literacies and Language Education. Springer International Publishing, Cham. https://doi.org/10.1007/978-3-319-02252-9

Street, B.V., May, S. (Eds.), 2017. Literacies and Language Education. Springer International Publishing, Cham. https://doi.org/10.1007/978-3-319-02252-9

Tarigan, Henry Guntur. 1995. The Basic Principles of Literature. Bandung: Angkasa.

Zamroni. 2000. The Paradigm of Future Education. Yogyakarta: Bigraf Publishing.

70 | ISLLAC : Journal of Intensive Studies on Language, Literature, Art, and Culture 